\title{
INTERFACES DA SAÚDE MENTAL NO BRASIL
}

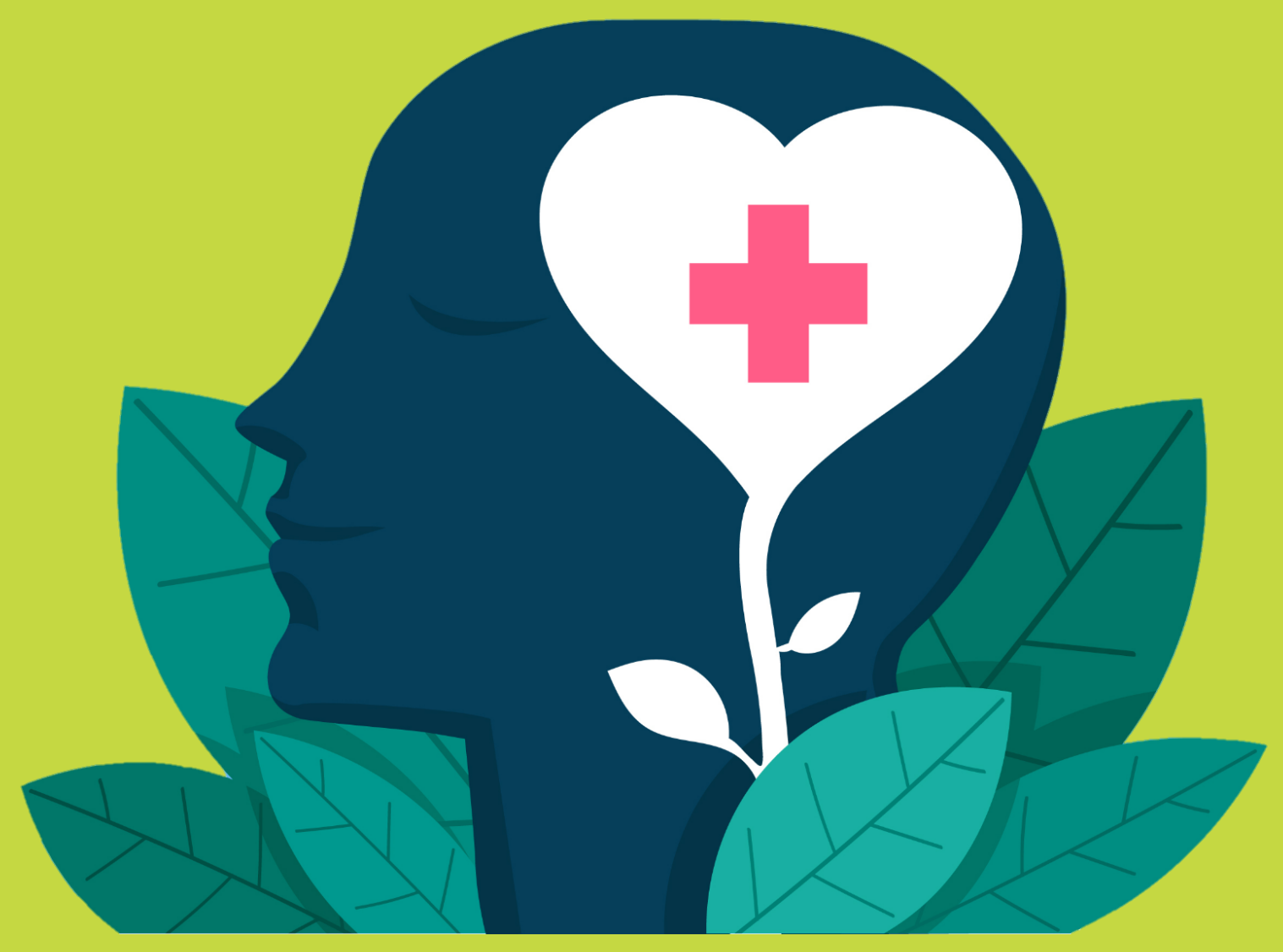

MAYARA MACÊDO MELO

Organizadora
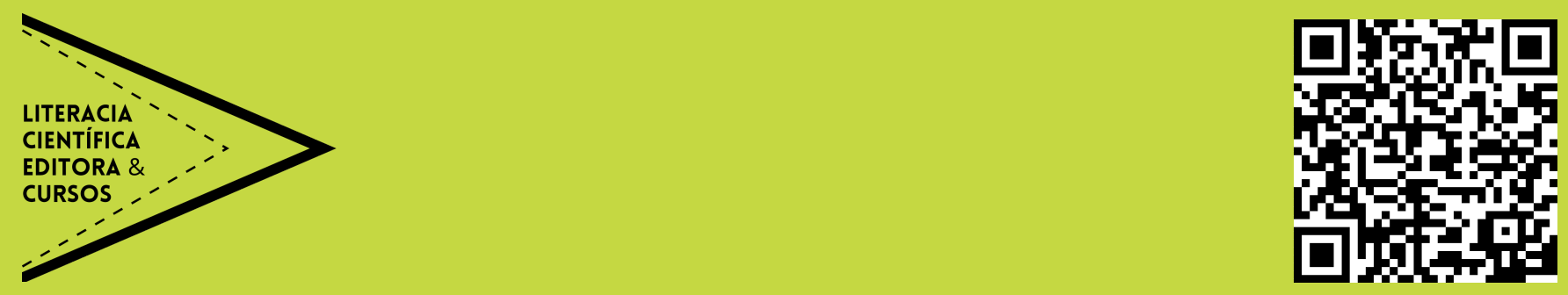